\title{
Central pontine myelinolysis in a 7-year-old boy
}

\author{
JOHN J. KEPES, CAROL ANN REECE, AND DWIGHT K. OXLEY \\ From the Departments of Pathology and Oncology and Pediatrics, \\ University of Kansas Medical Center, Kansas City, U.S.A.
}

In 1959, Adams, Victor, and Mancall reported four cases of a hitherto undescribed condition: a demyelinating process in the central portion of the pons which they very accurately called central pontine myelinolysis. Since that time 13 more cases have been reported in the literature and five others presented at meetings.

This condition is characterized by disintegration of myelin sheaths in the centre of the pons extending from the midline raphe to more lateral portions. The extension is frequently, but not always, symmetrical. The lesion, particularly if small, may be overlooked on gross examination of the pons. In some instances a blurring of the normal structures can be seen and the area usually has a softer consistency than the surrounding structures. Some cavitation in the very centre of the lesion may be present but is usually detected only by microscopic examination. The most characteristic feature is the extensive breakdown of the myelin sheaths in the area involved. The breakdown products are sudanophilic. Axons are relatively well preserved and the neurons of the pontine nuclei may show only minimal degenerative changes. The changes usually appear to be older and more severe in the midline. Clinical findings depend on the size of the lesion and on the presence of associated diseases. Coma with gradually developing quadriplegia is frequently seen.

The first three patients of Adams et al. (1959) were chronic alcoholics and the possibility of this condition being directly due to the noxious effects of alcohol has been considered but their fourth patient and almost half of the patients since reported were not alcoholics. Nearly all of these patients, however, suffered from some form of malnutrition, dehydration, electrolyte imbalance, or a combination of these factors. In all the reported cases, central pontine myelinolysis entered the clinical picture as a final fatal complication in spite of the frequently successful corrective measures taken to combat dehydration, malnutrition, and electrolyte imbalance.

We had the opportunity to observe this condition in a 7-year-old boy who had a craniopharyngioma surgically removed and who died after a rather stormy post-operative course.

\section{REPORT OF CASE}

K.S., a 7-year-old white boy, was admitted to Kansas University Medical Center on September 7 1963, with a six-month history of weight loss associated with frontal headaches, a gradual diminution of vision, irritability, and increasing lethargy. One month before admission low-grade fever was noted, after which anorexia, enuresis, and 'tunnel vision' developed. The family history and past medical history were not contributory.

On examination he was $107.5 \mathrm{~cm}$. (43 in.) tall and weighed $19.75 \mathrm{~kg}$. His visual acuity in both eyes was $6 / 200$. Neurological examination was considered to be normal. Skull radiographs revealed suprasellar calcification and pneumoencephalography showed a filling defect in the third ventricle.

Because of a suspected craniopharyngioma a past record of height and weight was obtained. This suggested some diminution of his growth during the previous six to nine months. Response to Metopirone (SU-4885) was normal (Fig. 1). Other parameters of endocrine function were normal although his urinary water excretion seemed excessive at times.

On 1 August 1963 a craniotomy revealed a $4 \times 4 \times 4$ $\mathrm{cm}$. cystic calcified suprasellar craniopharyngioma verified histologically (Fig. 2). The tumour was completely removed and the procedure was well tolerated.

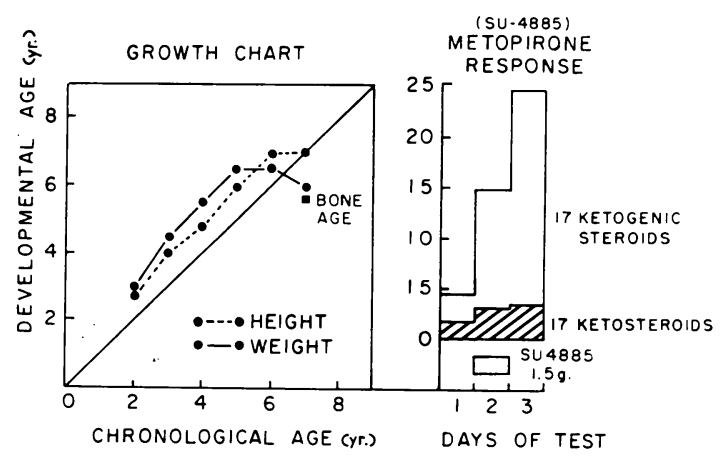

FIG. 1. Chart showing growth urinary response to metopirone. 


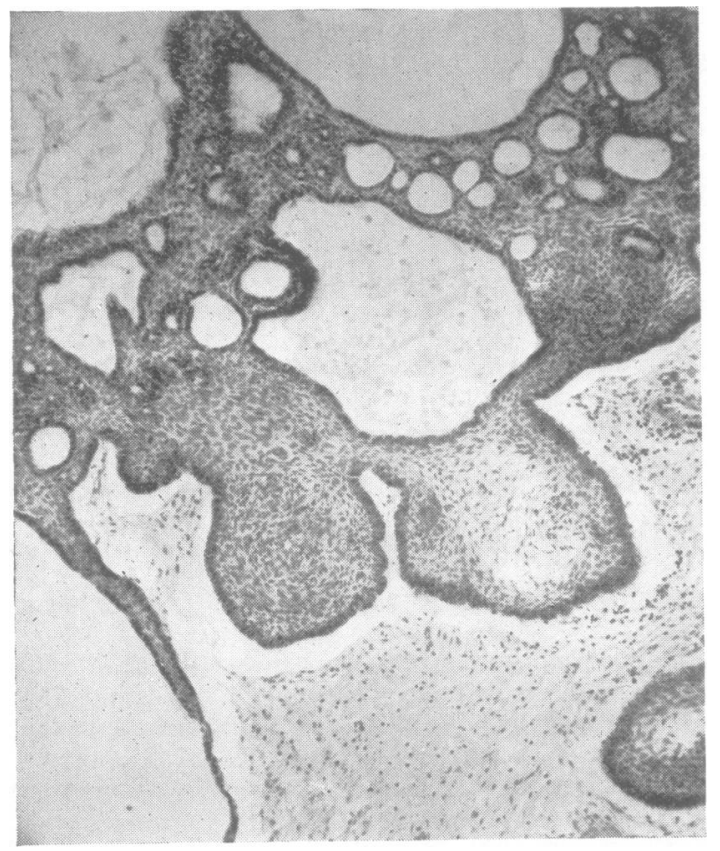

FIG. 2. Section from the tumour removed at operation shows the typical picture of a craniopharyngioma (haematoxylin-eosin).

Immediately upon awakening the boy responded to verbal commands, moved all four extremities, but did not speak. The pupils were unresponsive to light and the left plantar reflex was extensor. The following day sudden and severe dehydration developed (body weight dropped from $19 \cdot 75 \mathrm{~kg}$. to $17 \mathrm{~kg}$.) and subsequent water balance remained precarious (Fig. 3). Because of increasing unresponsiveness a right carotid arteriogram was performed on the fourth post-operative day. Although this suggested a frontal epidural clot, re-exploration on the fifth day revealed no abnormality. This procedure was not well tolerated and was followed by decerebrate posturing, irregular respiration, and generalized seizures. Decerebrate posturing continued intermittently until August 11.

Obvious diabetes insipidus had developed on the second post-operative day and although increasing amounts of intravenous aqueous Pitressin were administered no urinary concentration was evident. It was felt that the aqueous Pitressin had been pharmacologically ineffective. In addition large urinary losses of sodium were evident (Fig. 4) which also responded poorly to salt-retaining hormone (D.O.C.A.). Serum $\mathrm{Na}$ and $\mathrm{K}$ values are registered in Figure 5. Some improvement was noticed when 9-fluorohydrocortisone was given together with a concomitant increase in parenteral hydrocortisone.

On the eleventh post-operative day a urinary tract infection and pneumonia developed, initially responding to antibiotics (Furadantin and aqueous penicillin). Subsequent urine cultures revealed Pseudomonas aeruginosa which was inadequately controlled with Polymyxin B.

Neurological improvement was gradual. The child responded to verbal commands, took food by mouth and was able to sit up in a chair. He did not speak, however. On the thirty-first post-operative day the patient appearedo jaundiced and urinary water excretion abruptly rose to $500-1,000 \mathrm{ml}$./hour. He appeared extremely dehydrated. Despite increasing medications the child succumbed on the thirty-seventh post-operative day.

\section{GROSS NECROPSY FINDINGS}

At the time of the necropsy the body appeared to be well developed but dehydrated. The craniotomy wound was

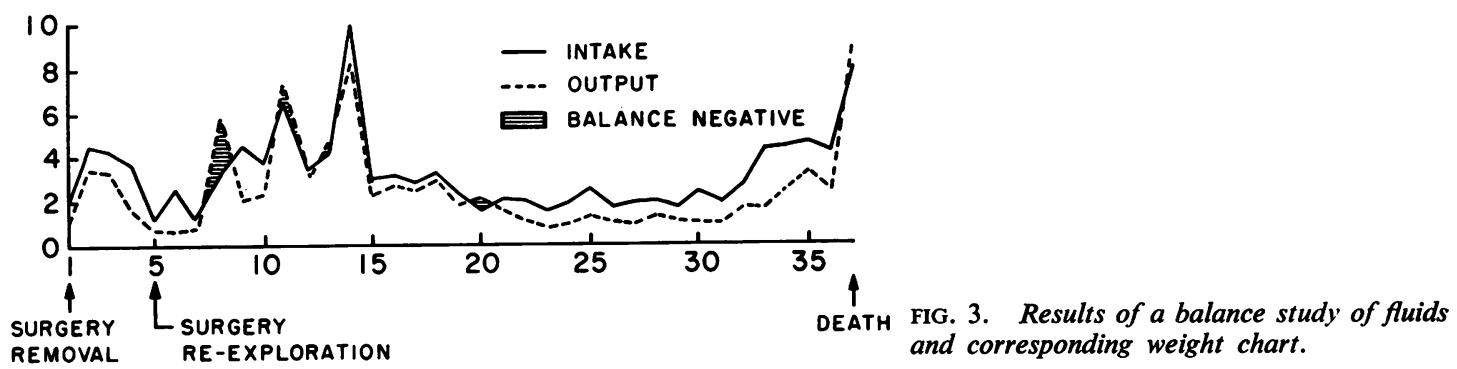

WEIGHT IN $\mathrm{Kg}$.

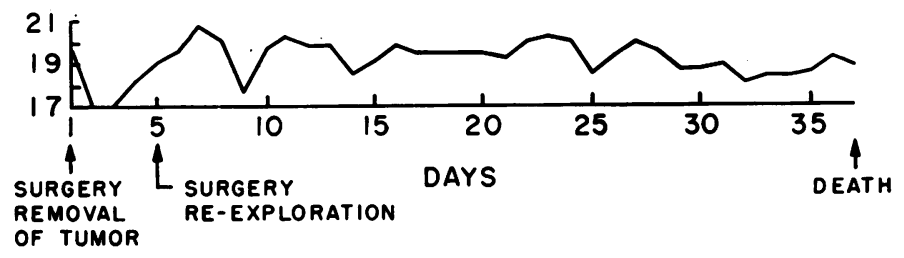




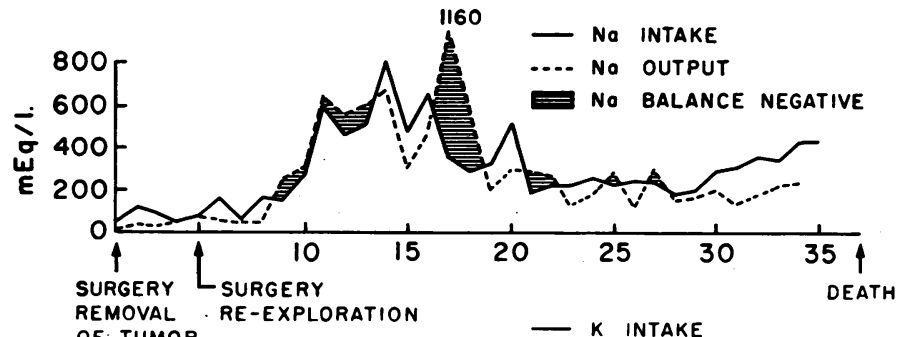

INTAKE

-.-- $K$ OUTPUT

FIGS. 4 and 5. Charts recording balance

” $K$ balance negative studies of urinary electrolytes.
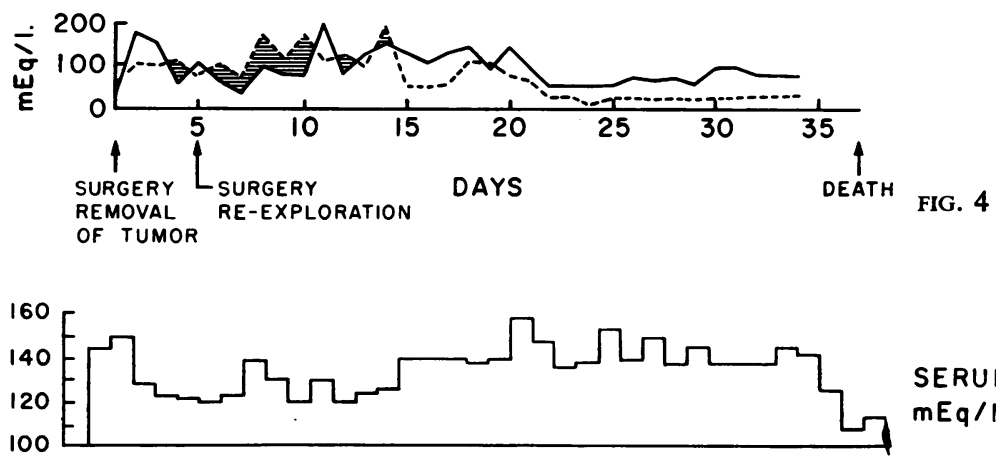

SERUM SODIUM

$m E q / I$.

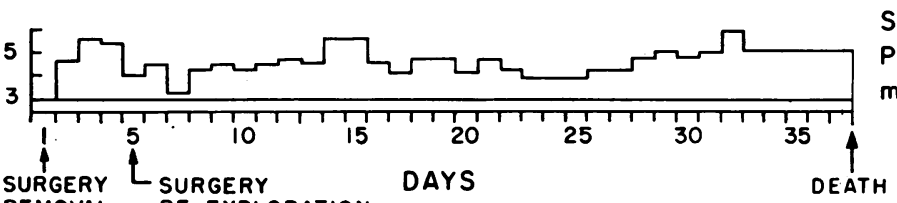

SERUM

POTASSIUM

$m E q / I$.

FIG. 5

well healed. Except for moderate atelectasis and congestion of the dorsal areas of the lungs the thoracic and abdominal viscera showed no abnormalities. The brain weighed $1,340 \mathrm{~g}$. The arteries of the circle of Willis were well developed and patent throughout. The cerebral hemispheres were symmetrical and the convex surfaces were not unusual. On the basal surface the interpeduncular fossa was markedly widened and rounded in contour producing the negative image of a large round mass. The surface of the fossa was slightly rugged and granular with a yellow-brown discoloration suggestive of minimal haemorrhage in the past. No residual tumour was evident. The optic nerves and the chiasma appeared normal. The pituitary stalk was not identified. The pituitary gland itself showed no abnormalities. The mamillary bodies were markedly flattened and blended into the wall of the fossa caused by the tumour. Multiple coronal sections through the brain showed no abnormalities of the cerebral and cerebellar cortex and subcortical white matter. The basal ganglia appeared intact except for the right putamen which had minute foci of yellow-grey discoloration but was not otherwise grossly distorted. The ventricles were symmetrical, unobstructed and undilated, and their ependymal lining was smooth.
Sections through the upper and middle pons revealed a slight greyish discoloration of the central portion of the pons with blurring of the structures. This became most evident when one traced the transverse fibres of the white matter towards the centre (Fig. 6). The greatest transverse diameter of the lesion was about $1.5 \mathrm{~cm}$.

\section{MICROSCOPIC FINDINGS}

Myelin stains of the pons showed a central area of demyelination extending symmetrically into the lateral halves of the pons (Fig. 7). However, the lesion was not quite symmetrical at every level. A higher-power view of the edge of the lesion (Fig. 8) revealed a rather abrupt breakdown of the myelin sheaths, fragments of myelin being engulfed in macrophages. These fragments stained positively for myelin whereas macrophages closer to the centre of the lesion contained only sudanophilic material (Fig. 9). Bodian's silver impregnation for nerve fibres showed some loss of axons but nerve fibres were still relatively well preserved even in completely demyelinated areas (Fig. 10). Ganglion cells of the nuclei pontis failed to show significant alterations (Fig. 11) and one could see normal appearing nerve cells next to lipid-laden macro- 


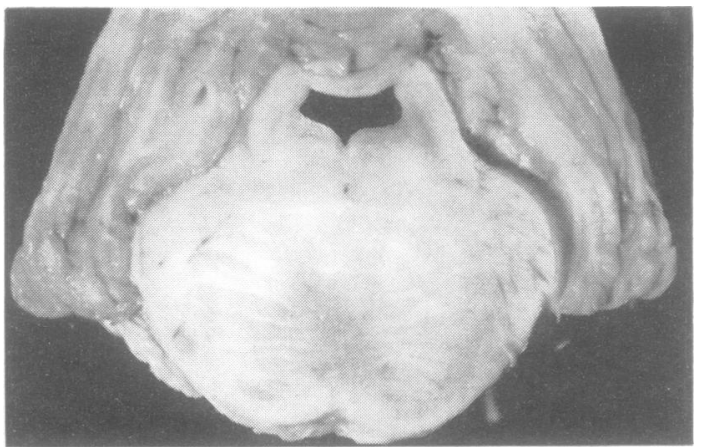

FIG. 6. A slightly depressed, irregular, greyish area occupies the centre of the pons interrupting the transverse white fibre tracts.

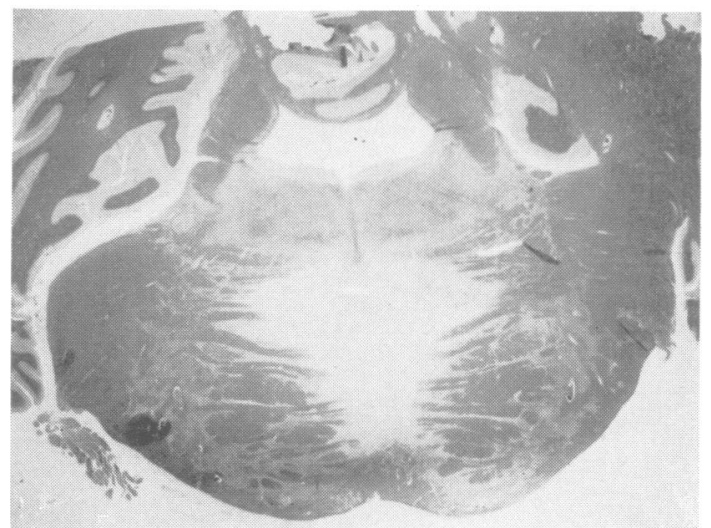

FIG. 7. A central area of demyelination extends symmetrically into the lateral halves of the pons (Weigert's myelin stain).

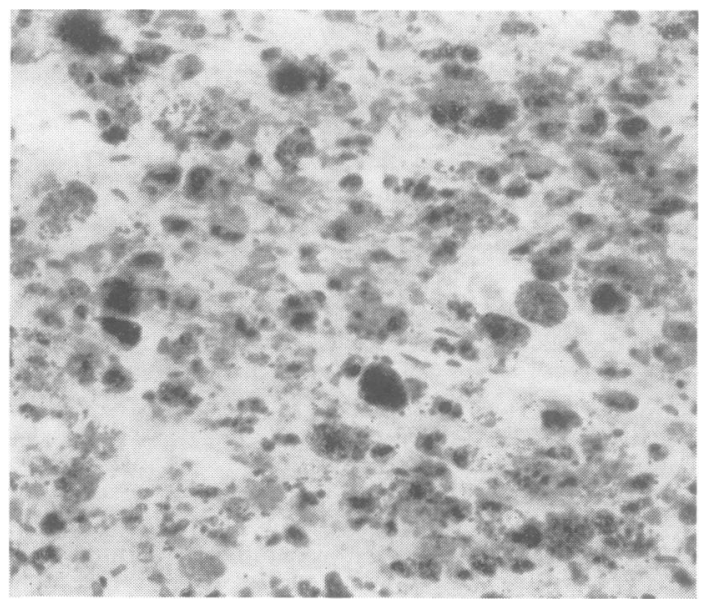

FIG. 9. Phagocyles in the centre of the lesion are loaded with sudanophilic breakdown products (Oil Red-O stain).

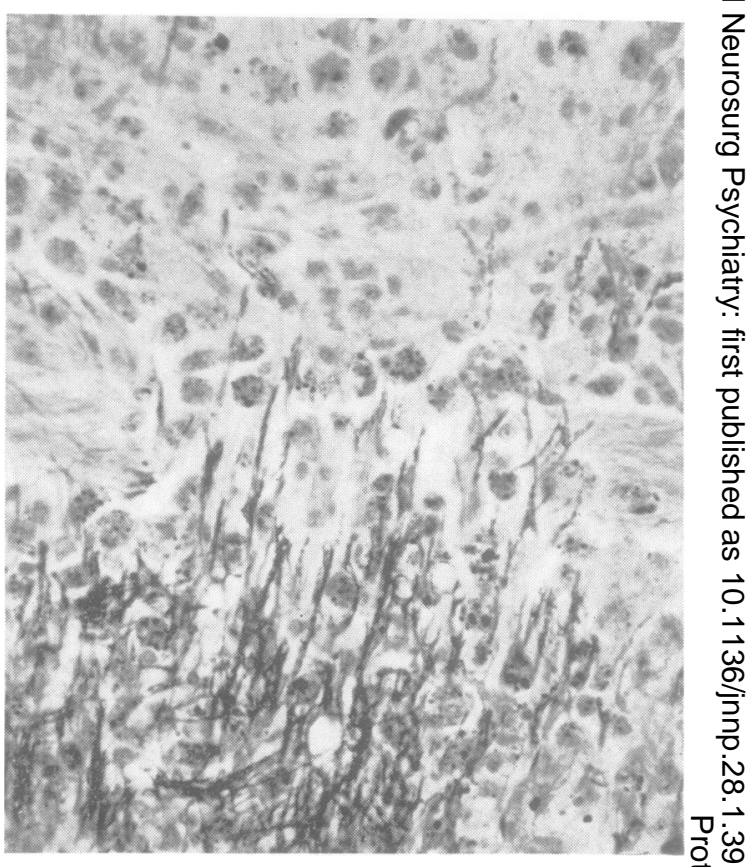

FIG. 8. The edge of the pontine lesion shows a rathen abrupt breakdown of the myelinated fibres. Phagocyte $\overrightarrow{\mathbb{B}}-$ close to the edge still contain stainable myelin particleg $T$ whereas those closer to the centre do not take up myelin 8 stain (Weigert's stain).

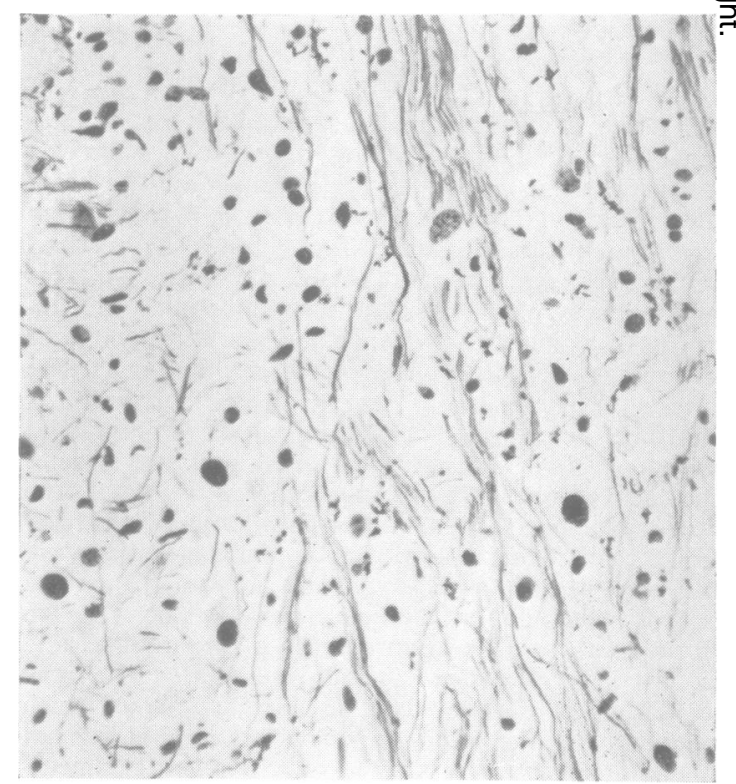

FIG. 10. Axons are relatively well preserved within the demyelinated area (Bodian's silver impregnation). 


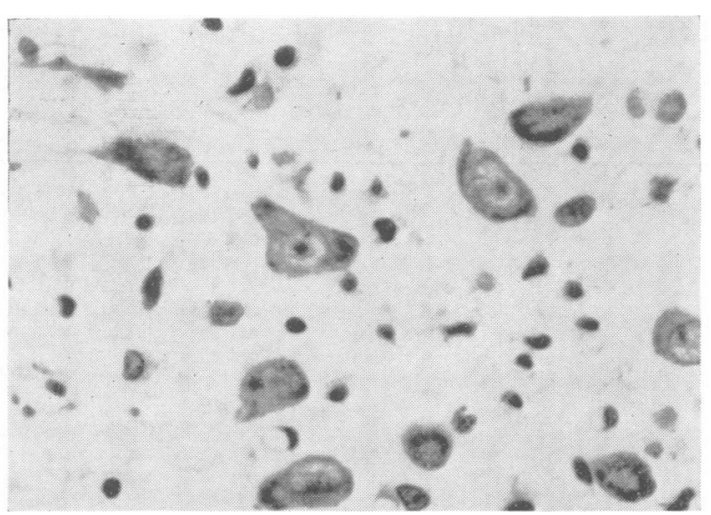

FIG. 11. Nerve cells of the nuclei pontis show no alterations in the area of the lesion (Nissl stain with buffered thionin).

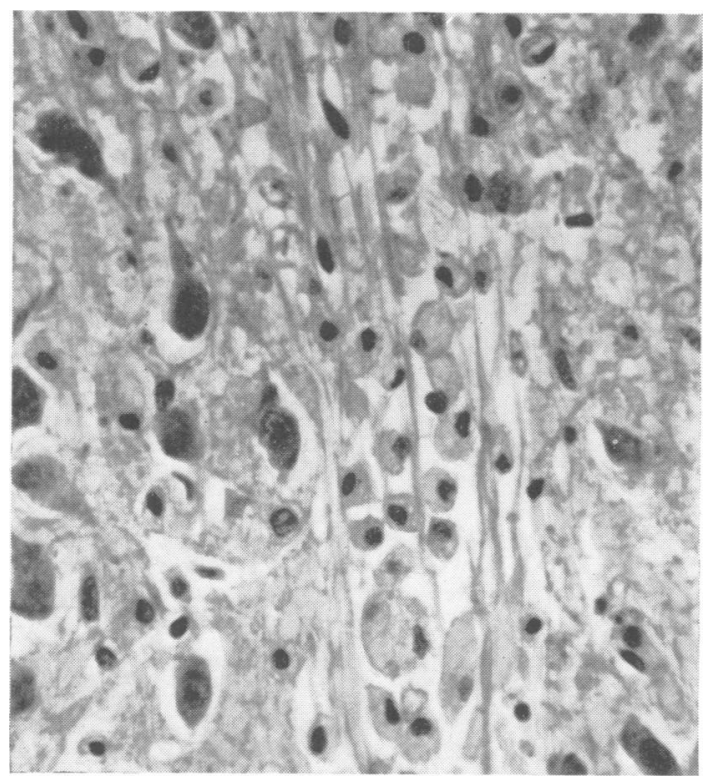

FIG. 12. This section shows side by side naked axons surrounded by fat-laden gitter cells and normal appearing neurons of the nuclei pontis (haematoxylin-eosin).

phages surrounding naked nerve fibres (Fig. 12). There was no proliferation of astrocytes and oligodendroglial cells were diminished in numbers.

No inflammatory cells were seen within or around the lesion. The pontine changes were regarded as characteristic of central pontine myelinolysis as described by Adams et al. (1959) and subsequent authors.

There was no sign of ascending or descending degeneration in the midbrain or medulla nor were there other foci of demyelination. Several small areas in the right putamen showed focal nerve cell disintegration with some accumulation of microglial cells but no gitter cells were observed. The pressure of the tumour had produced a deformity of the hypothalamus which made the analysis of anatomical structures difficult. Nevertheless it was noted that no massive infarction or haemorrhage had occurred in the nuclei. The tumour bed showed no residual tumour tissue; a few scattered haemosiderin-laden macrophages were encountered in the edge of the surgical wound.

\section{DISCUSSION}

Since Adams et al. (1959) reported the first four cases in 1959 , central pontine myelinolysis has been considered a distinct entity. In all cases reported so far, the condition developed as a terminal and fatal complication of some pre-existing disease. Of the reported 22 cases, 20 occurred in adults (Table I). Our case is the third one observed in a child.

As to the nature of this destructive lesion of the pons it can be justly classified as a demyelinating disease in the accepted sense: the destruction involves primarily myelin sheaths, the axons being relatively preserved and usually the nerve cells are also quite well preserved in the affected areas. Inflammatory reaction in the form of lymphocytes and possibly other elements is seldom observed and then not in excess of the reactive inflammation seen with other acute demyelinating diseases.

We do not know whether the hypothetical injury affects the myelin sheaths directly or through the oligodendroglial cells. A paucity of the latter in the area of injury has been observed in most cases, including our own. The dependence of myelin sheaths on healthy oligodendroglial cells is generally accepted and it is therefore quite possible that derangements of nutrition and hydration affect the myelin sheaths through the oligodendrocytes.

Astrocytes usually remain more or less in the background but possibly the lack of astrogliosis is simply due to the relatively recent nature of the lesions and to the fact that at the time of death active tissue destruction was still in progress. Astrogliosis was observed in the first case of Cole, Richardson, and Segarra (1964).

The aetiology of the lesion is still unknown. The possibility of a vascular lesion or anoxia is discarded by most authors because of the good preservation of nerve cells and the distribution of the lesion which does not follow any particular vascular pattern. Also, the arteries of the brain were found to be intact in most cases, including our own.

About half of the reported cases were alcoholics but alcohol has, at best, only an indirect effect by disposing to malnutrition and, in several cases, to copious vomiting after an episode of heavy drinking.

Vomiting apparently preceded the pontine changes in at least nine of the reported cases. In the nonalcoholic patients it was due to a variety of causes: 
TABLE I

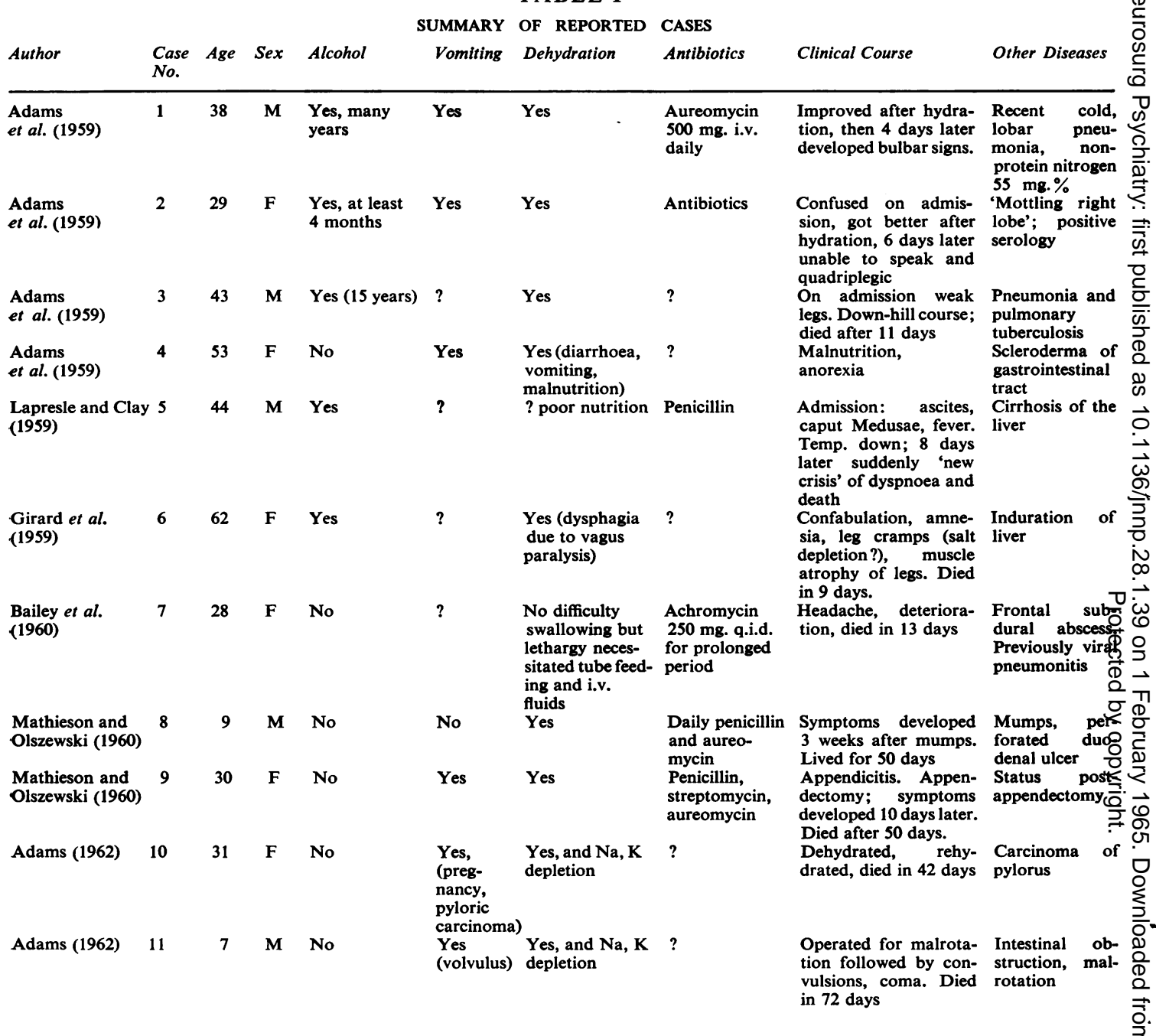

scleroderma of the oesophagus in the fourth case of Adams et al. (1959), a pyloric carcinoma in the first case of Adams (1962), malrotation of intestines with volvulus in the second case of the same author, and appendicitis in the second case of Mathieson and Olszewski (1960).

In the cases of Bailey, Bruno, and Ober (1960) and of Girard, Plauchu, Tommasi, and Bourrat (1959) no vomiting was recorded but both patients were dehydrated; in the case of Bailey et al. (1960) lethargy necessitated tube feeding and administration of intravenous fluids. The second patient of Cole et al. (1964) also had to be tube fed for a month and the patient of Aki, Miyazakim, Takeuchi, Shimamine, and Aisawa (1961) for two months. The patient of Girard et al. (1959) suffered from dysphagia, ap- parently due to nuclear paralysis of the vagus nerve. The dehydration was made more severe by diarrhoea in the fourth case of Adams et al. (1959).

Vomiting of course may lead not only to dehydration but also to electrolyte loss. The patient of Berry and Olszewski (1963) had severe metabolic acidosis and hypokalaemia. Severe sodium loss was well documented in the two cases of Adams (1962). Our own patient lost fluids because of diabetes insipidus which responded poorly in pitressin. The marked loss of sodium and chloride in this case occasioned the clinical diagnosis of 'salt-losing nephropathy'. The patient of Girard et al. (1959) was dehydrated and suffered from severe 'leg cramps' which could very likely have been the manifestation of salt loss. 
TABLE I-continued

\begin{tabular}{|c|c|c|c|c|c|c|c|c|c|}
\hline Author & $\begin{array}{l}\text { Case } \\
\text { No. }\end{array}$ & Age & $\operatorname{Sex}$ & Alcohol & $\begin{array}{c}\text { SUMMARY } \\
\text { Vomiting }\end{array}$ & $\begin{array}{l}\text { OF REPORTED } \\
\text { Dehydration }\end{array}$ & $\begin{array}{l}\text { CASES } \\
\text { Antibiotic }\end{array}$ & Clinical Course & Other Diseases \\
\hline Aki et al. (1961) & 12 & 39 & $\mathbf{M}$ & No & $?$ & 'Cachexia' & $?$ & $\begin{array}{l}\text { In comatose state, } \\
\text { tube fed for } 2 \text { months } \\
\text { before death. Became } \\
\text { cachetic and anaemic } \\
\text { before death }\end{array}$ & $\begin{array}{l}\text { Sphenoid ridge } \\
\text { meningioma } \\
\text { (inoperable) }\end{array}$ \\
\hline
\end{tabular}

\begin{tabular}{|c|c|c|c|c|}
\hline $\begin{array}{l}\text { Lapresle and } \\
\text { Milhaud (1962) }\end{array}$ & 13 & & & \\
\hline $\begin{array}{l}\text { Green et al. } \\
\text { (1962) }\end{array}$ & 14 & & & Yes \\
\hline $\begin{array}{l}\text { Green et al. } \\
\text { (1962) }\end{array}$ & 15 & & & No \\
\hline $\begin{array}{l}\text { Green et al. } \\
\text { (1962) (only } \\
\text { abstract of paper } \\
\text { available) }\end{array}$ & 16 & & & No \\
\hline Klavins (1963) & 17 & 44 & $F$ & Yes \\
\hline
\end{tabular}

?

Aleu and Terry
(1963)

\begin{tabular}{|c|c|c|c|c|c|c|c|}
\hline $\begin{array}{l}\text { Aleu and Terry } \\
\text { (1963) }\end{array}$ & 19 & 51 & F & Yes & Yes & $\begin{array}{l}\text { Yes, anorexia, } \\
\text { malnutrition }\end{array}$ & Tetracycline \\
\hline $\begin{array}{l}\text { Berry and } \\
\text { Olszewski (1963) }\end{array}$ & 20 & 51 & $\mathbf{M}$ & $\begin{array}{l}\text { Yes, but not } \\
\text { in the last few } \\
\text { years }\end{array}$ & No & $\begin{array}{l}\text { 'Metabolic acid- } \\
\text { osis, hypokalae- } \\
\text { mia' }\end{array}$ & $?$ \\
\hline $\begin{array}{l}\text { Cole et al. } \\
\text { (1964) }\end{array}$ & 21 & 40 & $\mathbf{F}$ & Yes, in excess & No & $\begin{array}{l}\text { Malnutrition } \\
\text { (pellagra-like } \\
\text { changes in cor- } \\
\text { tical nerve cells) }\end{array}$ & $\begin{array}{l}\text { Penicillin } \\
\text { hypersensi- } \\
\text { tivity reaction } \\
\text { was cause of } \\
\text { admission }\end{array}$ \\
\hline $\begin{array}{l}\text { Cole et al. } \\
\text { (1964) }\end{array}$ & 22 & 49 & $\mathbf{M}$ & Yes & $?$ & $\begin{array}{l}\text { Dehydration } \\
\text { and } \\
\text { malnutrition }\end{array}$ & $\begin{array}{l}\text { Penicillin, } \\
\text { chloram- } \\
\text { phenicol }\end{array}$ \\
\hline Present case & 23 & 7 & $\mathbf{M}$ & No & No & $\begin{array}{l}\text { Dehydration } \\
\text { and electrolyte } \\
\text { imbalance }\end{array}$ & $\begin{array}{l}\text { Penicillin, } \\
\text { furadantin, } \\
\text { polymyxin B }\end{array}$ \\
\hline
\end{tabular}

\author{
Probable dehy- Penicillin, \\ dration (uraemia) tetracycline
}

$$
\text { before death }
$$

Died of circulatory arrest Hepatic cirrhosis Hepatic cirrhocis and diabetes Reticulum cell sarcoma and diabetes

Headache, nose bleed, Bronchouraemia pneumonia, membranous glomerulonephritis. Arteriolar nephrosclerosis.

Yes Penicillin, streptomycin, streptomycin
tetracycline Signs of Wernicke's Perforated col-
encephalopathy (op- onic ulcer. Perithalmoplegia) plus tonitis. Necrofever. Died in 13 days. tizing pneumonia

Anorexia 1 month with Nutritional cirmalnourishment. 7 rhosis of liver days pta. chills, fever, with areas of nausea, vomiting necrosis

Fifteen years before Lung abcesses, death 'transverse mye- gastric ulcer litis' left him paraplegic While in hospital had Penicillinone day of diplopia induced skin followed by sudden and mucosal death

Tube fed for $\mathbf{3 0}$ days Moderately before death. Diplopia fatty liver, pneumonia, Wernicke's encephalopathy

Died 37 days after Status postbrain surgery with signs operative reof diabetes insipidus. moval of cranio-
The effect of sodium depletion on the nervous system has been nicely demonstrated by the experiments of Faris and Poser (1964) who used sodium loss to produce hemiplegia in dogs with previously reduced carotid circulation. The same authors, with Davis (Faris, Davis, and Poser, 1962), reported a patient who developed coma after losing sodium and potassium on a low-salt diet combined with chlorothiazid and corticoids. The patient returned to normal cerebral function after electrolyte and fluid replacement therapy. The situation is of course somewhat different from the conditions under discussion. Whereas dehydration and loss of electrolytes probably play an important role in bringing about central pontine myelinolysis, rehydration and restoration of normal electrolyte balance did not prevent the development of the lesion in the reported cases. It is probable that additional factors play a role in the development of the pontine lesions. Aleu and Terry (1963) suggested that these factors must be relatively new environmental elements (possibly recently introduced drugs), since malnutrition and dehydration have been with us for many centuries whereas central pontine myelinolysis, a rather easily detectable lesion, had not been observed before the late 1950s.

PROGNOSIS All the cases of central pontine myelinolysis described to date were detected at necropsy only and the condition seems to be a fatal one. It is conceivable that the process may be arrested in some patients and even 'heal' with gliosis. Some 'old infarcts' of the pons could have possibly derived from a healed focus of central pontine myelinolysis. 
There are histological indications, however, which would suggest that the lesion, once established, is progressive with bilateral extension from the raphe.

As mentioned before, the changes in the midline usually appear older than those in the periphery.

ASSOCIATE DISEASES In addition to dehydration and malnutrition in general, several patients described in the literature suffered from severe debilitating diseases, which included pneumonia (first three cases of Adams et al., 1959; Klavins, 1963; Berry and Olszewski, 1963; Cole et al., 1964, case 2), pulmonary tuberculosis (Adams et al., 1959, case 3), hepatic cirrhosis (Lapresle and Clay, 1959; Girard et al., 1959, case 2; Aleu and Terry, 1963; two cases of Green, Sung, and Wolf, 1962), and membranous glomerulonephritis (Klavins, 1963).

Of special interest are those cases in which a preexistent pathological condition involved the central nervous system. Bailey's case had a subdural abscess following purulent sinusitis. The patient of Berry and Olszewski (1963) was paraplegic due to 'transverse myelitis' 15 years before death. The patient of Aki et al. (1961) had a sphenoidal ridge meningioma and our patient had a successful removal of a large craniopharyngioma. The relationship of such conditions to the pontine demyelinating process is not clear. It is quite likely that whatever connexion exists between them is indirect and depends on such mechanisms as dehydration, electrolyte imbalance, and other factors as in patients without pre-existent disease of the central nervous system.

Of the alcoholic group of patients, five (the third case of Adams et al., 1959; the case of Girard et al., 1959; Lapresle and Clay's patient, 1959; case 1 of Aleu and Terry, 1963; case 2 of Cole et al., 1964) had clinical or anatomical signs of Wernicke's encephalopathy.

Some of the patients who died with central pontine myelinolysis had additional, mostly minor, changes of the central nervous system detected at necropsy. The relationship of these to the main lesion in the pons is not clear. Adams et al. (1959) described pallor of Goll's fascicle in the cord as well as some diapedesic haemorrhages in the medulla in one of their patients, while another patient had cortical nerve cell changes similar to those seen in pellagra. Similar cortical changes were seen in Cole's first case. Mathieson and Olszewski (1960) described bilateral putamen and caudate atrophy and cerebellar lesions around the dentate nuclei as well as degeneration of neurons in the pallidum and Sommer's sector of the hippocampus (their patient had several severe convulsions). Aleu and Terry (1963) described some Alzheimer type 2 cells in the pallidum of one of their patients, but the same patient suffered from advanced cirrhosis. Perhaps the most $\underset{\mathbb{D}}{Z}$ widespread demyelinating lesions were encountered by Klavins (1963) who found in addition to the main on pontine lesion, foci of demyelination in the arbor vitae, the basis of the peduncles, and the optic 0 radiation. In our own case there was some neuronal degeneration with microglial reaction in the right $\stackrel{5}{\text {. }}$. putamen but demyelinating changes were restricted to the pons.

Why the white matter of the pons should be more $\overrightarrow{\vec{F}}$ vulnerable than other myelinated areas is of course $\stackrel{\infty}{\frac{7}{\circ}}$ not known and Mathieson evoked the 'pathoclysis' theory of Vogt to explain the selective vulnerability $\frac{\bar{\sigma}}{\bar{\omega}}$ of pontine white matter. One can hardly avoid the $\frac{\vec{\sigma}}{\vec{D}}$ analogy of the selective involvement of the corpus $\propto$ callosum in Marchiafava-Bignami's disease. Since $\%$ the latter condition also occurs in alcoholics, a $\overrightarrow{0}$ possible relationship between the two conditions has been scrutinized by several authors but none of the $\vec{\omega}$ reported cases of alcoholics with central pontine? myelinolysis had changes in the corpus callosum.

\section{SUMMARY}

A 7-year-old boy was operated on for a cranie후 pharyngioma and the tumour was completely r $\overrightarrow{\mathrm{P}}$ 을 moved. Post-operatively he developed signs of dis $\rightarrow$ betes insipidus with dehydration and electrolyte inf balance. These were difficult to control. The chite $\frac{D}{0}$ never quite regained consciousness and died on the 37 th post-operative day. Necropsy revealed an area extensive demyelination in the centre of the pows $\vec{x}$ identical with the lesion described by Adants of et al. (1959) as central pontine myelinolysis. The literature of this condition is reviewed and the importance of dehydration, electrolyte imbalance, and probably other as yet unrecognized factors, is emphasized.

\section{ADDENDUM}

After this paper had been accepted, a series of cases of central pontine myelinolysis was reported by Chason, Landers, and Gonzalez (1964). These patients were all adults and with one exception, alcoholics.

\section{REFERENCES}

Adams, J. H. (1962). Central pontine myelinolysis. In Proc. 4th int. Congress of Neuropathology, München, 1961, vol. 3, edited by 으 H. Jacob, pp. 303-308. Thieme, Stuttgart.

Adams, R. D., Victor, M., and Mancall, E. L. (1959) Central pontine myelinolysis. A hitherto undescribed disease occurring in $\mathrm{O}$ alcoholics and malnourished patients. Arch. Neurol. Psychiat. (Chic.), 81, 154-172.

Aki, M., Miyazakim, M., Takeuchi, K., Shimamine, T., and Aisawa, 을 S. (1961). Central pontine myelinolysis. Psychiat. Neurol.

Aleu, F. P., and Terry, R. D. (1963). Central pontine myelinolysis. Arch. Path., 76, 140-146. Bailey, O. T., Bruno, M. S., and Ober, W. B. (1960). Central pontine N
myelinolysis. Amer. J. Med., 29, 902-906. 
Berry, K., and Olszewski, J. (1963). Central pontine myelinolysis. A case report. Neurology (Minneap.), 13, 531-537.

Chason, J. L., Landers, J. W., and Gonzalez, J. E. (1964). J. Neurol. Neurosurg. Psychiat., 27, 317-325.

Cole, M., Richardson, E. P., and Segarra, J. M. (1964). Central pontine myelinolysis. Further evidence relating the lesion to malnutrition. Neurology (Minneap.), 14, 165-170.

Faris, A. A., Davis, J., and Poser, C. M. (1962). Iatrogenic electrolyte disturbances with neurologic manifestations. Ibid., 12, 571-576.

-, and Poser, C. M. (1964). Experimertal production of focal neurological deficit by systemic hyponatremia. Ibid. 14, 206-211.

Girard, P. F., Plauchu, M., Tommasi, M., and Bourrat, C. (1959). Un nouvel aspect anatomique des encéphalopathies alcooliques. La démyélinisation centrale du pont. Lyon. méd. 202, 1195-1200.
Green, D., Sung, J. H., and Wolf, A. (1962). Central pontine myelinolysis. (Abstract of paper presented at the 14th Annual Meeting of the Amer. Acad. Neurol.) Neurology (Minneap.), $12,302$.

Klavins, J. V. (1963). Central pontine myelinolysis. J. Neuropath. exp. Neurol. 22, 302-317.

Lapresle, J., and Clay, R. (1959). Nécrose centrale du pied de la protubérance dans une encéphalopathie alcoolique avec lésions des corps mamillaires. Rev. neurol., 101, 769-774.

- and Milhaud, M. (1962). Lésions du système nerveux central après arrêt circulatoire. Etude de 10 cas. Presse méd., 70, 429-432.

Mathieson, G., and Olszewski, J. (1960). Central pontine myelinolysis with other cerebral changes. Neurology (Minneap.), 10, 345354. 